\title{
The effects of chemical pollution on the bioturbation potential of estuarine intertidal mudflats
}

\begin{abstract}
Bioturbation by benthic infauna has important implications for the fate of contaminants as well as for changes to the sediment structure, chemistry and transport characteristics. There is an extensive literature dealing with the influence of sedimentary variables on the structure and function of infaunal marine and estuarine organisms but less is known of the converse, the influence of biota on sedimentary structure. Although some work has been carried out regarding spatial and temporal patterns of bioturbation, little attention has been given to the effects of pollution. The paper gives a framework of animal sediment relationships in an intertidal environment and discusses the general role of macrofauna in structuring and modifying sedimentary features. A brief outline of the various techniques used for quantifying the degree of bioturbation is given and some of these techniques have then been used to demonstrate the effect of a petrochemical discharge on the bioturbation potential of intertidal communities in the Humber estuary, eastern England. These studies indicate an increase in bioturbation with increasing distance from the source of pollution, not only because of differences in abundance, animal size and depth of activity but also because of the difference in species composition between the communities. As a means of interpreting the responses, the species present have been broadly classified in terms of their feeding strategy and sediment modification potential. The paper concludes by discussing the potential impact, in terms of effect on sediment transport, of selectively removing the different guilds (by pollution).
\end{abstract}

Key words Bioturbation - Estuarine pollution . Sediment properties $\cdot$ Macrofauna $\cdot$ Humber estuary

Communicated by H. Asmus and R. Asmus

K. Mazik ( $) \cdot$ M. Elliott

Department of Biological Sciences and Institute of Estuarine and Coastal Studies, University of Hull, Hull, HU6 7RX, UK e-mail:k.mazik@biosci.hull.ac.uk

\section{Introduction}

The effects of sediment characteristics on the distribution of benthic invertebrates have been extensively studied (Gray 1974 in Jones and Jago 1993; Gray 1981), although Snelgrove and Butman (1994) argue that there is poor evidence to support some of the theories given. Correlations between grain size and species distribution have been made (Petersen 1913; Jones 1950; Sanders 1958), leading to generalisations of distinct associations between animals and specific sediment types (Snelgrove and Butman 1994). Heterotrophic marine macro-organisms are predominantly suspension or deposit feeders with deposit feeders tending to dominate in muddy habitats (Rhoads 1974). Rhoads and Young (1970) suggested that suspension feeders were largely excluded from fine, unstable sediments due to the clogging of their delicate respiratory structures by suspended material, whilst deposit feeders were found at comparatively low densities in coarser sediments as a result of their lower organic content. However, this general pattern of segregation between the two feeding guilds is not always observed (Snelgrove and Butman 1994) and the mechanisms determining organism distribution are clearly poorly understood. It is evident that the occurrence of a species in a particular habitat is due not to one factor alone but to the complex interaction between particle size, organic and microbial content, hydrodynamic and chemical conditions, and biological interactions which makes a habitat suitable for a particular species. Conditions such as these are variable on a spatial and temporal scale and it is therefore not surprising that correlations between fauna and grain size have been weak.

Although the effect of the sediment characteristics on benthic fauna has been relatively well studied, much less appears to be known about the effect of the organisms on the sediment properties, particularly with reference to sediment transport. The activity of benthic animals has a profound effect on their environment (de Wilde 1991; Meadows 1991; Wheatcroft et al. 1994), resulting in significant alteration of the sediment properties (Winston 
and Anderson 1971; Rhoads 1974; Jones and Jago 1993). These physical, chemical and biological changes may have some effect on sediment stability and erosion (Widdows et al. 1998a,b). As the majority of the particles in muddy substrata are of a size which may be ingested or otherwise manipulated by benthic organisms, the degree of bioturbation tends to be greater than that in coarser sediments (Rhoads 1974). Rhoads (1967) stated that surface sediments, wherever deposit feeders are abundant, may be completely reworked several times before being isolated from further biological activity by additional sedimentation.

Sediment transport studies, in relation to animal $/ \mathrm{mi}$ crobial activity, have generally involved the use of various types of flume in order to measure critical erosion velocities. These studies have involved both field (e.g. Widdows et al. 1998a,b) and laboratory (e.g. Meadows and Tait 1989; Davis 1993) measurements. In addition to this, attempts have also been made to quantify the level of bioturbation caused by various species and faunal compositions. Methods used include the deliberate addition of inert particles (e.g. glass beads) to the sediment (Mahut and Graf 1987; Wheatcroft 1992), the use of labelled particles (Olmez et al. 1994; Wheatcroft et al. 1994; Krezoski et al. 1995) to act as tracers, the measurement of natural radionuclide deficits (Smethie et al. 1981; Wheatcroft and Martin 1996) within the sediment and various techniques to directly measure sediment displacement (Rhoads 1967; Hickson 1994; Retraubun et al. 1996). The degree of bioturbation is species specific and is closely related to the feeding mode and depth of the organism concerned, together with its motility, size and abundance as well as community composition (Rhoads 1974; Rhoads and Boyer 1982).

Estuarine and coastal waters have long received large volumes of domestic and industrial waste, the environmental effects of which have long been cause for concern. The fine-grained and cohesive nature of estuarine sediments dictates that contaminants are likely to be adsorbed onto particles and thus incorporated within the sediment. Diagenetic processes within sediments lead to contaminants being sequestered within the sediments, especially under anaerobic conditions (e.g. Elderfield and Hepworth 1975; Libes 1992). A knowledge of the impact of animal activity on sediment dynamics is therefore of importance to the study of the fate of contaminants. It is generally accepted that increased levels of contamination adversely affect organism survival, growth and biomass and that communities in organically polluted areas do not progress beyond the pioneering stages of development (Pearson and Rosenberg 1978). These types of communities, with low species richness, a high abundance of r-strategists and low biomass, have been found to have less of an impact on the sediment than the more developed equilibrium communities (Meadows 1991). It is therefore hypothesised that bioturbation potential should increase as the level of contamination declines. With this, a reduction in sediment stability might be expected. These hypotheses are tested using bioturbation

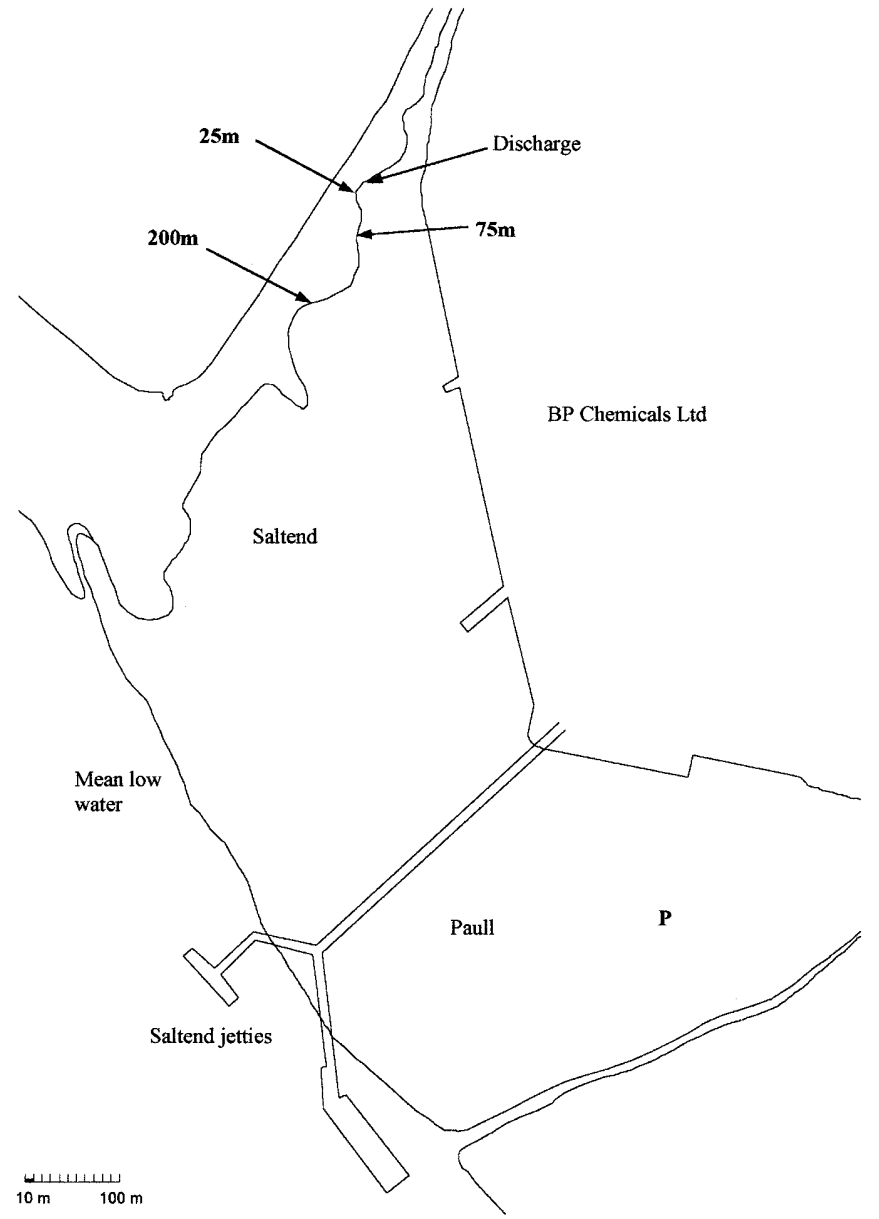

Fig. 1 Field study sites at Paull and Saltend $\left(53^{\circ} 44^{\prime} \mathrm{N}, 0^{\circ} 20^{\prime} \mathrm{W}\right)$

studies carried out along an organic pollution gradient in the Humber estuary, UK.

\section{Study area}

The study was carried out on the mudflats at Saltend and Paull (NGR TA 157278 and 164273 respectively) on the Humber estuary (Fig. 1). Effluent from BP Chemicals (Saltend) is discharged intertidally into a natural drain (Old Fleet Drain) running through the mudflat. The BP plant is Europe's largest acetic acid plant, producing over 600,000 t/year with a smaller amount of formic acid, acetone and acetyl aldehyde. The effluent, $95 \%$ of which is freshwater, is largely organic, although it does contain low concentrations of heavy metals, acidic, biodegradable and has a high biochemical oxygen demand (BOD). It is discharged at $30^{\circ} \mathrm{C}$ and therefore can be seen floating (as an oily sheen) on the surface of the water. At low water, the only source of dilution is a small freshwater stream entering the drain on the upper shore. Limited treatment, including neutralisation, recycling and some oil separation, is carried out although the company has a policy of waste minimisation rather than treatment prior to disposal. The effluent fulfils the re- 
Table 1 Sediment properties (means $\pm \mathrm{SE}$ ). Shear strength is at $10 \mathrm{~cm}$. Total metals includes $\mathrm{Mn}, \mathrm{Cr}, \mathrm{Zn}, \mathrm{Ni}, \mathrm{Cu}, \mathrm{Pb}, \mathrm{Fe}$, and $\mathrm{As}$

\begin{tabular}{|c|c|c|c|c|c|c|}
\hline & $25 \mathrm{~m}$ & $75 \mathrm{~m}$ & $200 \mathrm{~m}$ & Paull & $F$ & $P$ \\
\hline $\operatorname{Md} \phi$ & $7.53 \pm 0.004$ & $7.21 \pm 0.018$ & $7.03 \pm 0.008$ & $7.0 \pm 0.009$ & 43.4 & $<0.01$ \\
\hline$\%$ Silt/clay $(<63 \mu \mathrm{m})$ & $96.07 \pm 0.17$ & $97.84 \pm 0.76$ & $96.82 \pm 0.17$ & $97.22 \pm 0.11$ & 28.9 & $<0.01$ \\
\hline Organics (\% LOI) & $11.08 \pm 0.15$ & $10.9 \pm 0.38$ & $9.9 \pm 0.26$ & $8.7 \pm 0.32$ & 7.61 & $<0.01$ \\
\hline Porosity (\% water) & $41.1 \pm 0.43$ & $43.0 \pm 0.01$ & $45.1 \pm 0.41$ & $44.1 \pm 0.21$ & 16.9 & $<0.01$ \\
\hline Shear strength $(\mathrm{kPa})$ & $26.4 \pm 2.93$ & $9.6 \pm 2.1$ & $5.2 \pm 0.8$ & $5.0 \pm 0.71$ & 28.8 & $<0.01$ \\
\hline Chl- $a\left(\mathrm{mg} \mathrm{g}^{-1}\right)$ & $60.51 \pm 5.5$ & $52.74 \pm 8.82$ & $32.48 \pm 3.1$ & $30.89 \pm 4.8$ & 5.36 & $<0.05$ \\
\hline Total metals (ppm) & $41999.09 \pm 1722.69$ & $39670.92 \pm 436.47$ & $37142.57 \pm 1143.75$ & $33526.77 \pm 1246.41$ & 8.75 & $<0.01$ \\
\hline
\end{tabular}

quirements of the discharge licence issued by the Environment Agency and recent improvements to plant processes have led to a significant improvement in effluent quality. Modelling and ecological studies indicate that the mudflat at Paull (Fig. 1) is largely unaffected by the effluent and that the effect is localised around the point of discharge (Cambridge Coastal Research Unit 1996).

Both mudflats consist of fine-grained, cohesive sediments with a high organic content and dense invertebrate populations. They are therefore valuable feeding grounds for birds. Both sites are classed as Sites of Special Scientific Interest and are designated Special Protection Areas, under the Wild Birds Directive (79/409/EEC) (Institute of Estuarine and Coastal Studies 1996). Species of national importance include teal and golden plover. In addition, the area supports a fish assemblage as expected given the estuary's characteristics (Elliott and Dewailly 1995; Marshall and Elliott 1998).

\section{Methods}

\section{Sediment properties}

Sediment water content and organic content (expressed as weight loss on ignition) of the sediment were recorded in addition to redox potential, measured with a Russell CMPtR11/150 mm platinum rod electrode and a Russell RL100 meter. Particle size was measured using a Z1 Coulter Counter (Coulter Electronics) and sediment metal concentration data (analysed on a Perkin Elmer Plasma 40 emission Inductively Coupled Plasma instrument (ICPOES)) were available (C. Nikitik, University of Hull, personal communication). Digestion of $1 \mathrm{~g}$ oven-dried sediment was carried out by boiling in $10 \mathrm{ml}$ aqua regia $\left(3: 1 \mathrm{HCl} / \mathrm{HNO}_{3}\right)$. The cool digest was then diluted and filtered to a final volume of $50 \mathrm{ml}$. Chlorophyll $a$ and phaeopigment content were measured spectrophotometrically following overnight extraction in $10 \mathrm{ml} 90 \%$ acetone at $10^{\circ} \mathrm{C}$ and determined using the equations in Lorenzen (1967) and Wolff (1984). Sediment shear strength was measured using a Geonor H-10 field inspection vane. The above measurements were made at the $25 \mathrm{~m}, 75 \mathrm{~m}$ and $200 \mathrm{~m}$ sites at Saltend and also at Paull (Fig. 1).

\section{Faunal community analysis.}

Five $15 \mathrm{~cm}$ cores of $78 \mathrm{~mm}$ i.d. were taken from each of nine sites along a transect covering 0-300 $\mathrm{m}$ from the BP outfall at Saltend and one site at Paull. The cores were sieved through a $300 \mu \mathrm{m}$ mesh to retain the macrofauna and larger meiofauna and the sieve residue preserved in a solution of $4 \%$ formaldehyde with Rose Bengal vital stain. Animals were identified to species and their abundance recorded. Subsamples of oligochaetes (20 worms/sample) were mounted on slides in lactophenol and examined under a high power microscope. Animals were also divided into feeding groups based on the observations of Fauchald and Jumars (1979) and Barnes (1987). Broad classifications of sediment modification potential and bioturbation were made and each species was assigned a bioturbation score. Four classes of bioturbation were used: (1) biodiffusers, which mix at random with the sediment (Gerino et al. 1993); (2) conveyor-belt species, which actively transport sediment from some depth to the surface as a result of sub-surface deposit feeding or burrow excavation (Gerino et al. 1993; Wheatcroft et al. 1994); (3) regenerators, which transport sediment from the surface to some depth (Wheatcroft et al. 1994) and (4) surface depositors, which both feed and deposit faeces at the surface (Dauwe et al. 1998). Bioturbation scores were calculated according to the feeding and burrowing behaviour and motility of each species, using the scheme in Swift (1993).

Cluster analysis was used (Ludwig and Reynolds 1988) to group sites in terms of species, feeding types and sediment modification potential by calculating the Bray-Curtis Similarity Index, followed by the production of dendograms. Following cluster analysis, distinct groups were identified and wet biomass (tissue dry weight) was recorded for one site within each group. Bioturbation studies were also carried out at these sites. The data were tested for homogeneity of variance and statistical testing of site parameters was by analysis of variance followed by a posteriori comparison of means (Zar 1996).

\section{Bioturbation studies}

\section{Particle tracer techniques}

$22 \mathrm{~cm}$ long plastic tubes (68 mm i.d.) with fifteen $10 \mathrm{~mm}$ diameter holes drilled at $1 \mathrm{~cm}$ intervals between $2-17 \mathrm{~cm}$ were pushed into the sediment, surrounded by a stainless steel sheath, and placed at $25 \mathrm{~m}, 75 \mathrm{~m}$ and $200 \mathrm{~m}$ from the BP outfall. A further set of tubes was placed at Paull but could not be retrieved. The top $5 \mathrm{~cm}$ of the tube (with no holes) was left sticking out above the sediment surface so that the first hole was level with the surface of the sediment. $10 \mathrm{ml}$ of glass beads $(5 \mathrm{ml} 10-50 \mu \mathrm{m}$ diameter and $5 \mathrm{ml}$ 45-85 $\mu \mathrm{m}$ diameter) were poured onto the sediment surface, inside the tube, using a plastic pot with a $500 \mu \mathrm{m}$ mesh lid in order to ensure even spreading. Three tubes were placed at each site and covered with a plastic bucket with a $500 \mu \mathrm{m}$ mesh lid to protect the tubes against excessive sedimentation, to prevent the beads from being washed away and to prevent the escape of macrofauna. The tubes were left in situ for 6 weeks (8 July-20 August 1998) and checked periodically for signs of destruction and anoxia.

On return to the laboratory, the steel sheaths were removed and subsamples of sediment taken by spatula at $1 \mathrm{~cm}$ intervals. The sediment samples were placed in a solution of $50 \mathrm{ml} 6 \%$ hydrogen peroxide and the organic material was removed (Buchanan 1984). $10 \mathrm{ml}$ sodium hexametaphosphate was then added as a deflocculant and the samples allowed to stand overnight, following vigorous stirring. Samples were then restirred and five $2 \mathrm{ml}$ subsamples taken. These were allowed to settle overnight and the overlying water removed by pipette. Six drops of sediment were then mixed with an equal amount of $40 \%$ glycerol and mounted on slides. Following drying, the beads were counted under a light microscope at $10 \times$ magnification. Before use, the beads were examined under a 
Depth (cm)
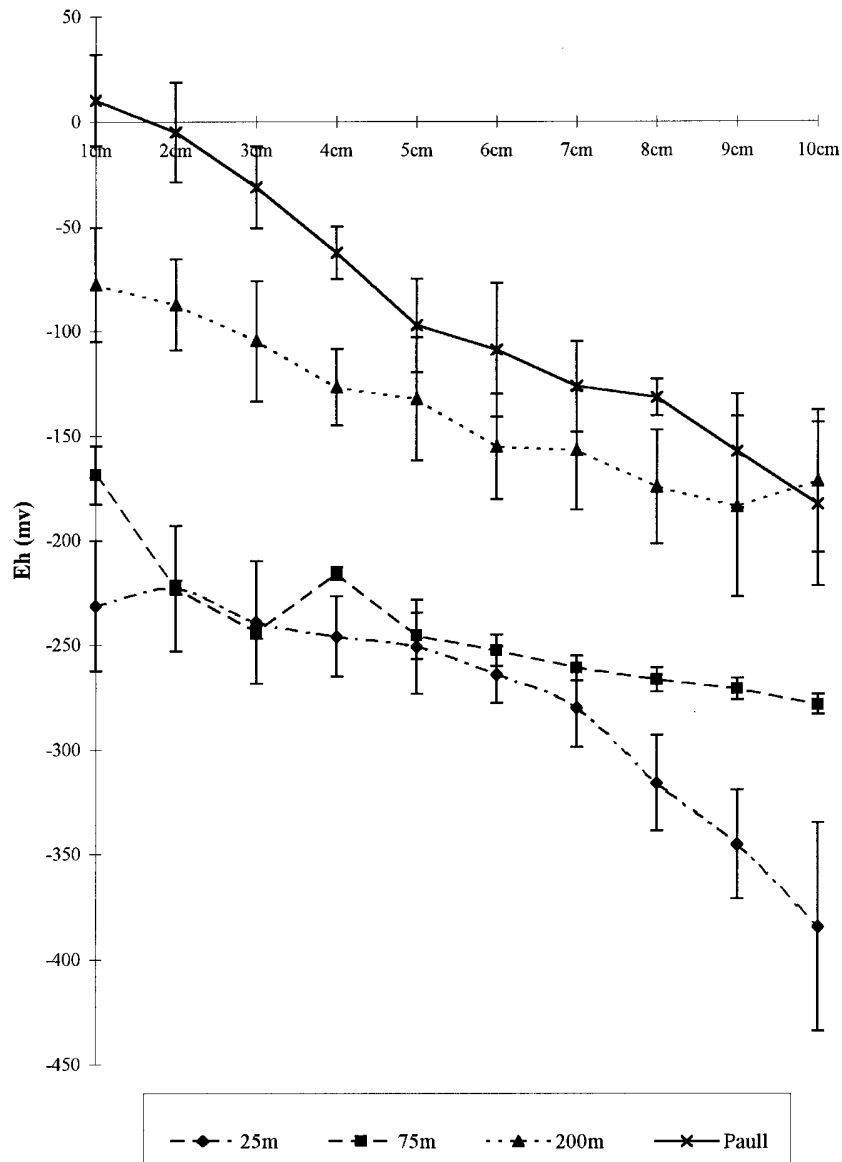

Fig. 2 Redox potential profiles (means \pm SE) for $25 \mathrm{~m}, 75 \mathrm{~m}$ and $200 \mathrm{~m}$ at Saltend, and at Paull scanning electron microscope in order to ensure that they were spherical and would be detectable amongst the sediment grains.

\section{Burrow depth and volume}

In order to determine the depth of animal activity and burrow volume within the sediment, resin casts were made using a modification of the method used by Nickell and Atkinson (1995). Casts were made in rectangular cores $(14.5 \times 12.5 \mathrm{~cm})$ using a low density polyester resin (AP101PA, Trylon) together with a styrene thinner and a liquid catalyst hardener (MEKP). Approximately $400 \mathrm{ml}$ resin was used for each core, containing $15 \%(\mathrm{v} / \mathrm{v})$ thinner and $1.5 \%$ hardener, which was sufficient to fill the burrows and leave an adequate hydraulic head to ensure that the burrows were completely filled. Four cores were taken from Saltend (25, 75, 150 and $200 \mathrm{~m}$ from the outfall) and one from Paull, to a depth of $15 \mathrm{~cm}$. The cores were stored at $10^{\circ} \mathrm{C}$ for at least $72 \mathrm{~h}$ to allow the burrows to open up and excess water to drain away. The resin was then slowly injected into each burrow using a $5 \mathrm{ml}$ syringe. After all the air and water had been expelled and each burrow was full, the resin was poured over the surface of the sediment to a depth of approximately $3 \mathrm{~cm}$. The casts were left to dry for at least $48 \mathrm{~h}$ under fume extraction, before they were removed from the cores and cleaned of sediment. Cleaning was carried out, over a $300 \mu \mathrm{m}$ sieve, using a small hose to gently wash away the mud. Any broken pieces of burrow were retained in the sieve.

\section{Results}

\section{Sediment properties}

The sediment at all four sites was found to be extremely fine-grained, with a high silt/clay $(<63 \mu \mathrm{m})$, organic and water content (Table 1). The median grain size at the $25 \mathrm{~m}$ site, however, was found to be significantly smaller $(P<0.01)$ than at the other sites. Here, the sediment was black within a few $\mathrm{mm}$ of the surface. Organic content, po-
Fig. 3 Changes in species richness, abundance and biomass (means \pm SE) at $25 \mathrm{~m}, 75 \mathrm{~m}$ and $200 \mathrm{~m}$ at Saltend, and at Paull

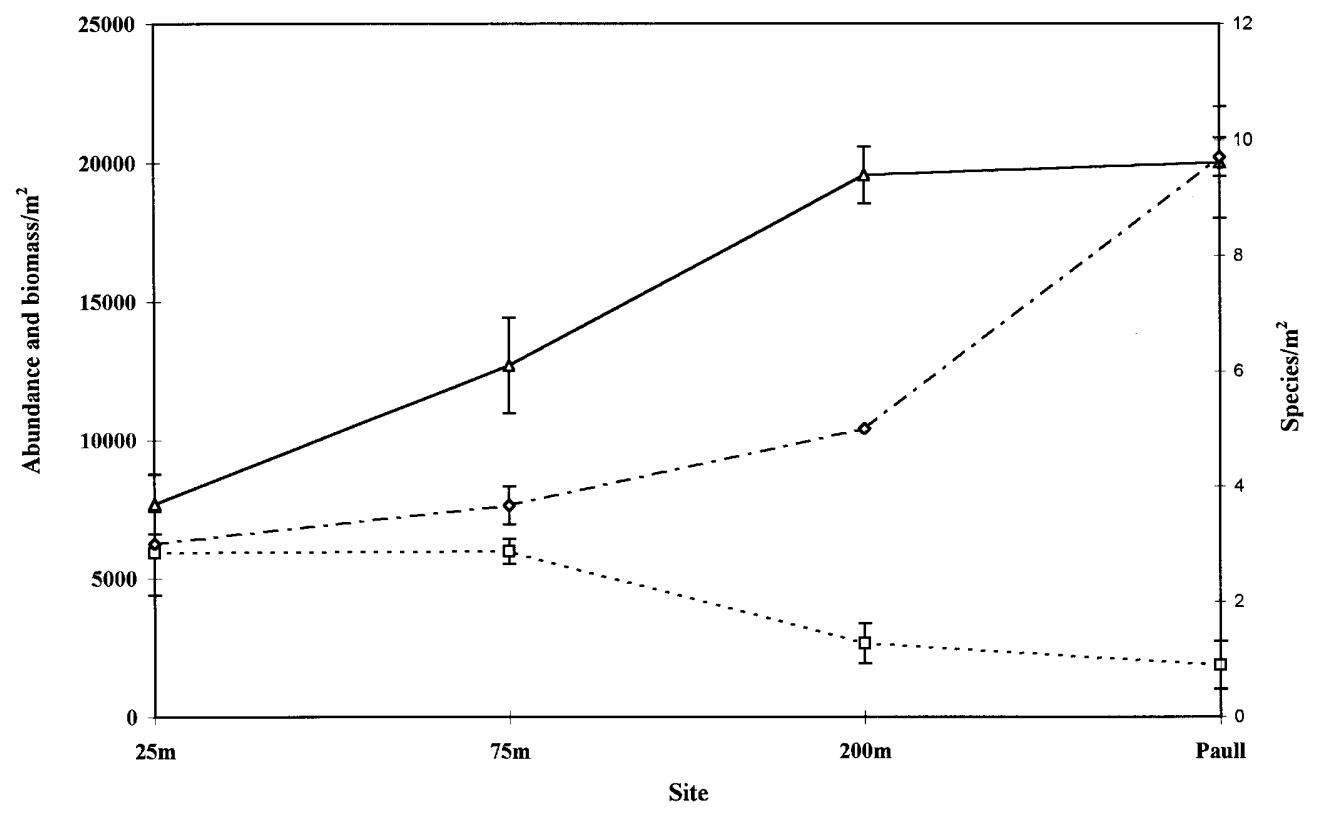




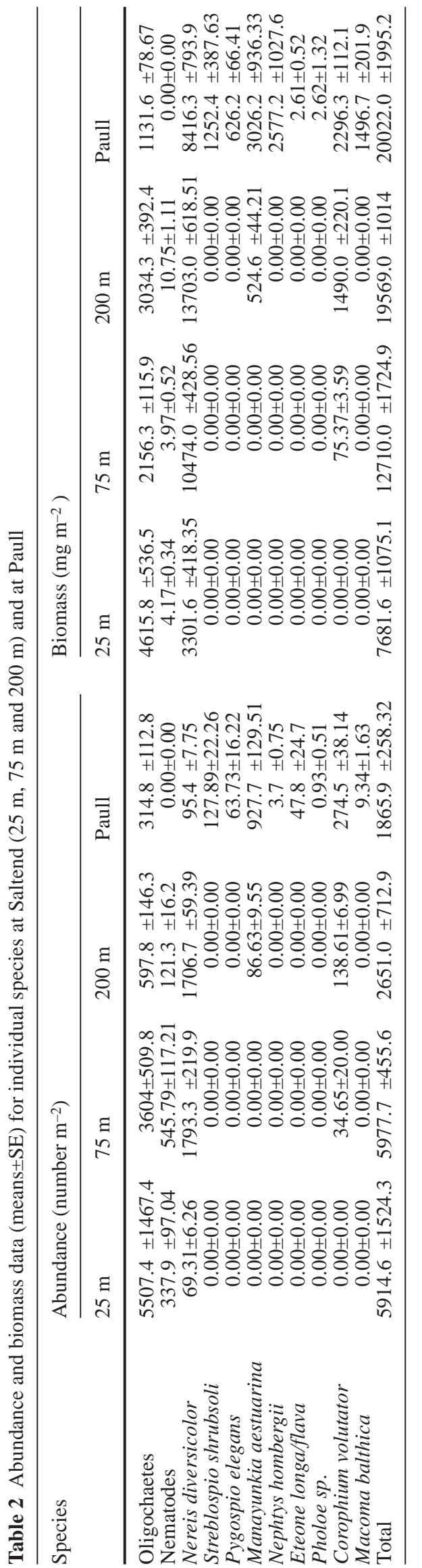

A. Species

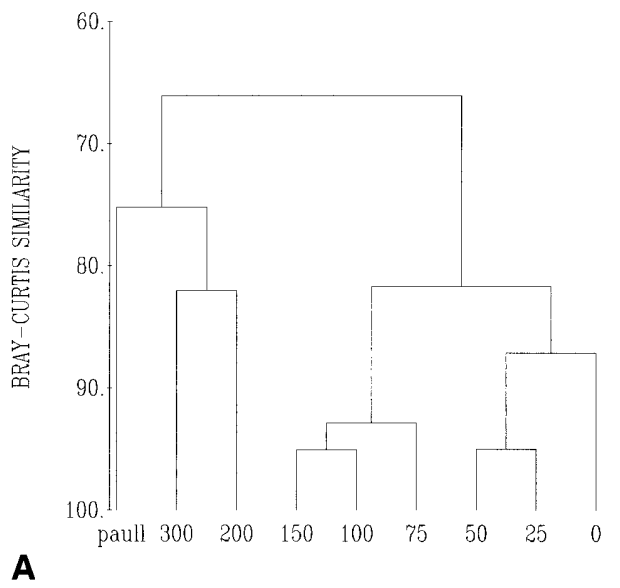

B. Feeding guilds

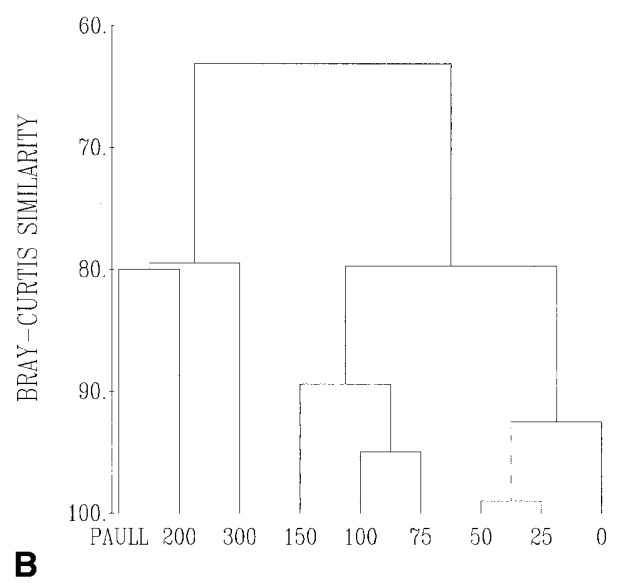

C. Sediment modification potential

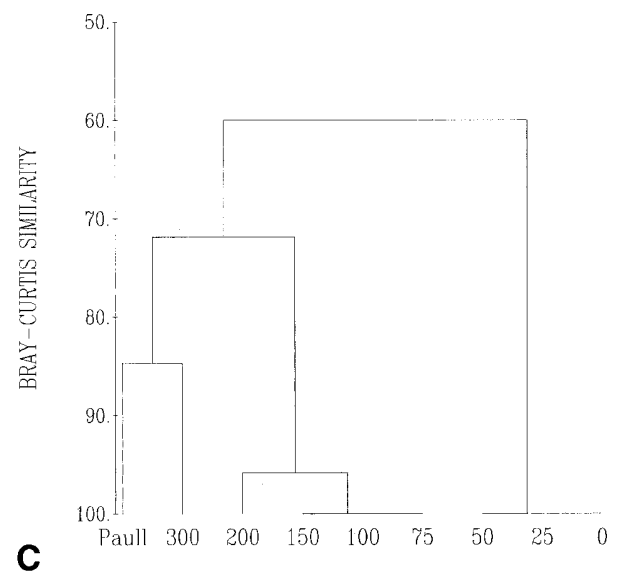

Fig. 4 Cluster analysis of species (A) and feeding guilds (B) present and of sediment modification potential (C) at Saltend (0-300 m) and at Paull

rosity, shear strength, total metal content $(P<0.01)$ and chlorophyll $a$ content $(P<0.05)$ all decline with increasing distance from the pollution outfall and with increasing distance down the shore. Post hoc analysis using Tukey's 
Table 3 Feeding strategy and sediment modification potential of the species at Saltend and Paull. Secondary feeding mechanisms are given in small print. SUBDF Subsurface deposit feeder; $S D F$ surface deposit feeder; SUSP suspension feeder; $C A R$ carnivore, $O M$ omnivore, $D E T$ detritivore, $B A C T$ bacteria, $B$ biodiffuser, $C$ conveyor-belt species, $R$ Regenerators, $S$ surface depositors. Bioturbation scores were calculated according to Swift (1993)

\begin{tabular}{|c|c|c|c|c|}
\hline Species & Feeding & $\begin{array}{l}\text { Sediment } \\
\text { modification }\end{array}$ & $\begin{array}{l}\text { Sediment } \\
\text { modification } \\
\text { score }\end{array}$ & Location \\
\hline $\begin{array}{l}\text { Oligochaetes } \\
\text { (Tubificidae/ Enchytraeidae) } \\
\text { and Nematodes }\end{array}$ & $\begin{array}{l}\text { SUBDF } \\
\text { DET/BACT }\end{array}$ & $\mathrm{B} / \mathrm{C}$ & 6 & Saltend, Paull \\
\hline Nereis diversicolor & $\begin{array}{l}\text { SDF SUSP } \\
\text { OM }\end{array}$ & $\mathrm{R}$ & 9 & Saltend, Paull \\
\hline Streblospio shrubsoli & $\begin{array}{l}\text { SDF SUSP } \\
\text { DET/BACT }\end{array}$ & $\mathrm{R}$ & 3 & Saltend (300 m), Paull \\
\hline Pygospio elegans & $\begin{array}{l}\text { SDF SUSP } \\
\text { DET/BACT }\end{array}$ & $\mathrm{R}$ & 3 & Saltend (300 m), Paull \\
\hline Manayunkia aestuarina & $\begin{array}{l}\text { SDF SUSP } \\
\text { DET/BACT }\end{array}$ & $\mathrm{R}$ & 3 & Saltend (200 m), Paull \\
\hline Nephtys hombergii & CAR & $\mathrm{B} / \mathrm{R}$ & 5 & Paull \\
\hline Eteone longa/flava & CAR & $\mathrm{B} / \mathrm{R}$ & 5 & Paull \\
\hline Pholoe sp. & CAR & $\mathrm{B} / \mathrm{R}$ & 5 & Paull \\
\hline Corophium volutator & $\begin{array}{l}\text { SDF } \\
\text { DET/BACT }\end{array}$ & $\mathrm{R} / \mathrm{S}$ & 8 & Saltend (75 m), Paull \\
\hline Macoma balthica & $\begin{array}{l}\text { SDF SUSP } \\
\text { DET/BACT }\end{array}$ & $\mathrm{C}$ & 11 & Saltend (300 m), Paull \\
\hline
\end{tabular}

HSD test revealed that, in general, the $200 \mathrm{~m}$ and Paull sites were significantly different from both the $25 \mathrm{~m}$ and $75 \mathrm{~m}$ sites. The exception to this is the total metal concentration where the concentration at Paull is significantly lower than that at the $200 \mathrm{~m}$ site. A reduction in chlorophyll $a$ between the $25 \mathrm{~m}$ site and Paull may reflect the lower microphytobenthos populations as a combination of increased grazing pressure and a reduction in the time of sediment exposure to the air, with distance from the discharge. The sediment at all sites was anoxic although this was more pronounced at the $25 \mathrm{~m}$ site (Fig. 2) where $E_{\mathrm{h}}$ readings ranged from $<-200 \mathrm{mV}$ in the top $1 \mathrm{~cm}$ to $<-350 \mathrm{mV}$ at $11 \mathrm{~cm}$. These values are significantly lower $(P<0.05)$ than those at the corresponding depths at $75 \mathrm{~m}, 200 \mathrm{~m}$ and Paull where $E_{\mathrm{h}}$ ranged from $<-150$ to $<-300 \mathrm{mv}$, from $<-50$ to $<-150 \mathrm{mv}$ and from $>0$ to $<-150 \mathrm{mv}$, respectively.

Faunal community analysis

Figure 3 shows species richness, abundance and biomass data for the four sites with a list of species at each site being given in Table 2. There was a distinct decrease in abundance with distance from the point of discharge $(P<0.01)$ and biomass and number of species increased significantly $(P<0.05)$ between the $25 \mathrm{~m}$ site and Paull. Here, the $25 \mathrm{~m}$ and $75 \mathrm{~m}$ sites were found to differ significantly from the $200 \mathrm{~m}$ and Paull sites (Tukey's HSD test).

The cluster analyses (Fig. 4a-c) show three distinct groups, with the $0 \mathrm{~m}, 25 \mathrm{~m}$ and $50 \mathrm{~m}$ sites being more than $80 \%$ similar in terms of species, more than $90 \%$ similar in terms of feeding types and $100 \%$ similar in terms of sediment modification potential. The communities here consist largely of small oligochaete worms which are nonselective, head-down deposit feeders, feeding on detritus and bacteria. Nereis diversicolor, a selective surface de- posit feeder, also occurs in small numbers at this site. Using the scores given in Table 3, the sediment modification potential of these sites is 15 (based on the species present at the $25 \mathrm{~m}$ site). The $75 \mathrm{~m}, 100 \mathrm{~m}$ and $150 \mathrm{~m}$ sites contain large populations of $N$. diversicolor and small numbers of Corophium volutator. These sites are more than $90 \%$ similar in terms of species composition and feeding groups present. However, the $200 \mathrm{~m}$ site is also included in this group when sediment modification potential is considered, probably due to the absence of Macoma balthica, which is present at the $300 \mathrm{~m}$ site and at Paull and scores highly on the bioturbation scale. The sediment modification potential scores for these communities are 23 (based on the species present at $75 \mathrm{~m}$ ) and 26 (based on the species present at $200 \mathrm{~m}$ ) and are considerably higher than that of the $25 \mathrm{~m}$ site. The third group includes the $200 \mathrm{~m}$ and $300 \mathrm{~m}$ sites and Paull which are more than $80 \%$ similar in terms of feeding groups. However, there is less than $70 \%$ similarity between the species present at the $200 \mathrm{~m}$ and $300 \mathrm{~m}$ sites and Paull and, as already mentioned above, the $200 \mathrm{~m}$ site is dissimilar in terms of sediment modification potential. The total sediment modification score for $300 \mathrm{~m}$ and Paull is 58 (based on the species found at Paull). Here, the presence of $M$. balthica, a destabilising 'conveyor-belt' species, together with the presence of burrowing carnivorous polychaetes, is responsible for the difference between these sites and the remainder. In general, the reduction in pollution, as illustrated by reducing metal concentrations, a reduction in the degree of anoxia and reducing organic content, is coupled with an increase in species diversity. These were coupled with an increase in the diversity of feeding strategies, moving from a community dominated by non-selective head-down deposit feeders to a community composed of selective and non-selective surface and subsurface feeding detritivores, carnivores and omnivores, leading to greater potential for sediment modi- 
Fig. 5 Bead transport (means \pm SE), as an indication of bioturbation, for entire core (A), 0-5 cm, (B) and 6-15 cm (C) at $25 \mathrm{~m}, 75 \mathrm{~m}$ and $200 \mathrm{~m}$ (Saltend)

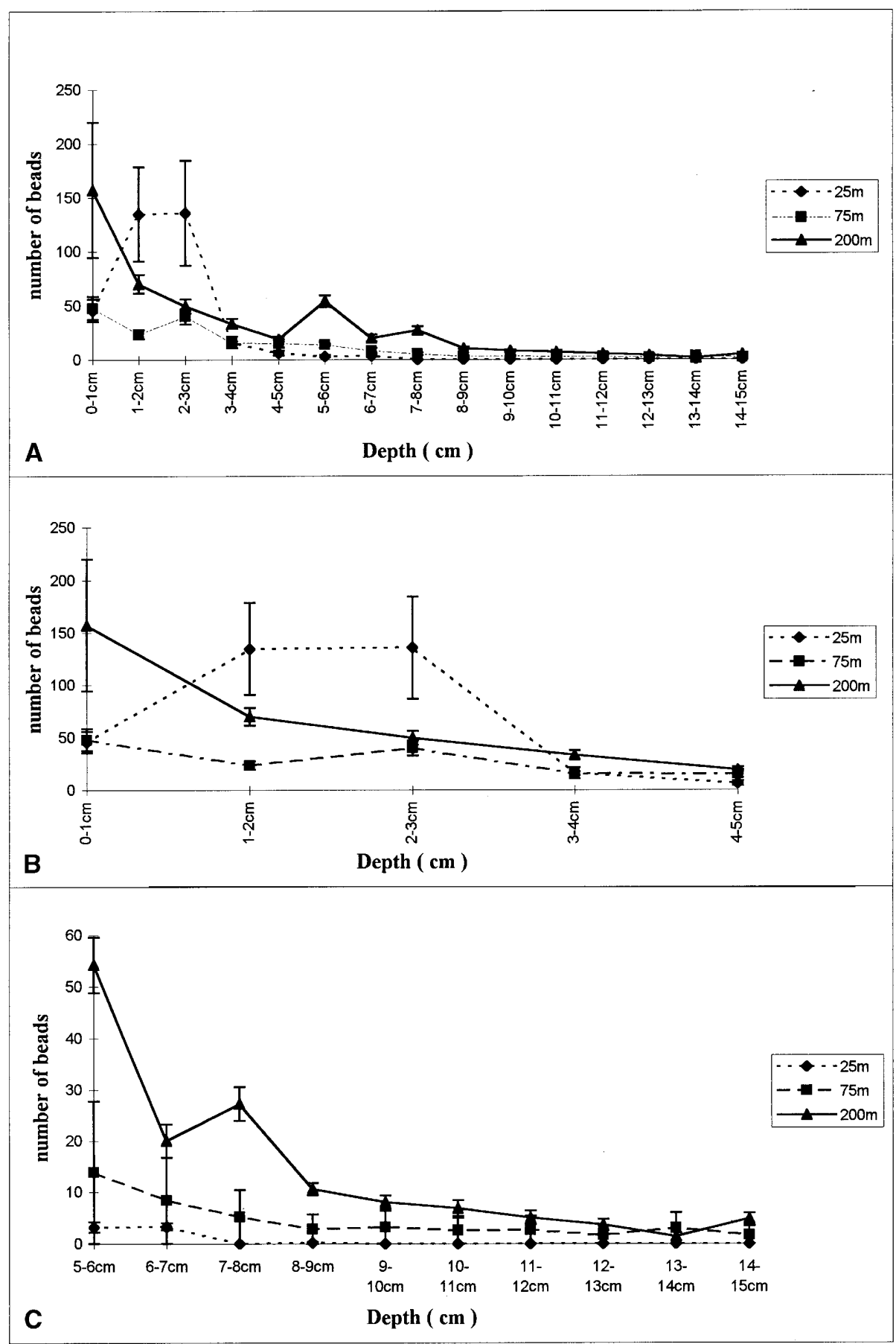

fication. In terms of bioturbation activity, there is also an increase in diversity from a community containing biodiffusers only (at $25 \mathrm{~m}$ ), through those being dominated by regenerators (at $75 \mathrm{~m}$ and $200 \mathrm{~m}$ ) to those containing all groups (at Paull).

\section{Bioturbation studies}

There were no apparent trends of glass bead distribution within the top $5 \mathrm{~cm}$ (with the exception of the $200 \mathrm{~m}$ site where the number of beads declined with depth) (Fig. 5). However, between $6 \mathrm{~cm}$ and $15 \mathrm{~cm}$, there were significant differences between the number of beads found in each core $(P<0.01)$. The maximum depth of bead penetration at the $25 \mathrm{~m}$ site was $6-7 \mathrm{~cm}$, where only very few beads were found. At the other sites, the beads were transported down the full length of the core with the number of beads at each depth being significantly greater at $200 \mathrm{~m}$ than at $75 \mathrm{~m}$, down to $10-11 \mathrm{~cm}$. These results suggest a well-defined increase in bioturbation with a reduction in the level of pollution. 


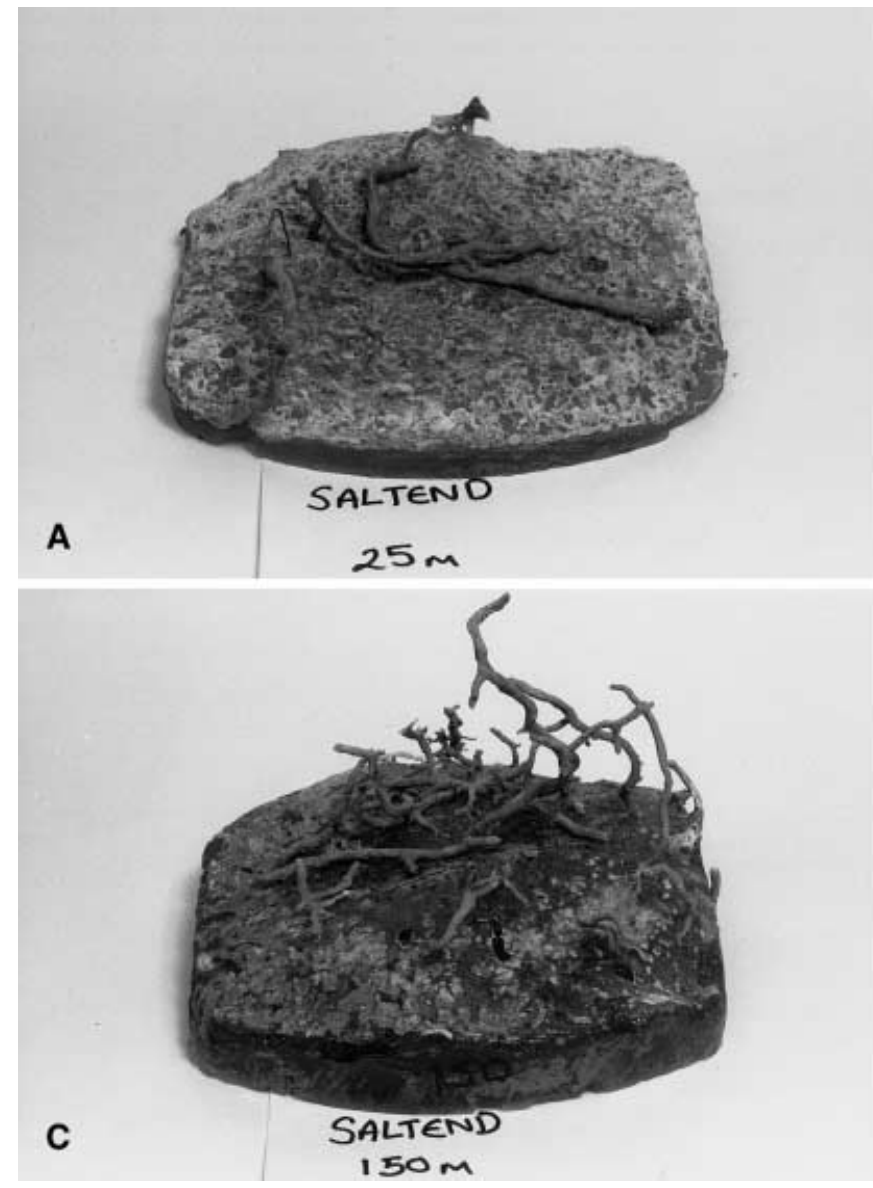

Fig. 6 Resin burrow casts from Saltend $25 \mathrm{~m}$ (A, maximum depth $3.5 \mathrm{~cm}), 75 \mathrm{~m}(\mathbf{B}$, maximum depth $7 \mathrm{~cm}), 150 \mathrm{~m}(\mathbf{C}$, maximum depth $7.5 \mathrm{~cm})$ and Paull (D, maximum depth $12 \mathrm{~cm}$ )

Figure 6 shows the resin casts from $25 \mathrm{~m}, 75 \mathrm{~m}, 150 \mathrm{~m}$ (the $200 \mathrm{~m}$ cast was badly damaged) and Paull. Although no quantitative data are given, these casts clearly show a reduction in burrow depth and volume with increasing pollution and therefore support the statement that bioturbation potential is reduced by pollution. Work is currently in progress to determine burrow volume and rate of cast production.

\section{Discussion}

\section{Bioturbation studies}

The study area was found to have a clear reduction in bioturbation with increasing levels of pollution, as shown by reduced burrow depth and volume (Fig. 6) and reduced bead transport into the sediment. However, no trends of bead distribution were found within the top $5 \mathrm{~cm}$ at the $25 \mathrm{~m}$ and $75 \mathrm{~m}$ sites. This is the depth zone of greatest bioturbation and it is possible that tracer profiles here have been flattened by the high numbers of oligochaetes and nematodes, which act as biodiffusers. At the $200 \mathrm{~m}$ site, the number of biodiffusers was reduced and

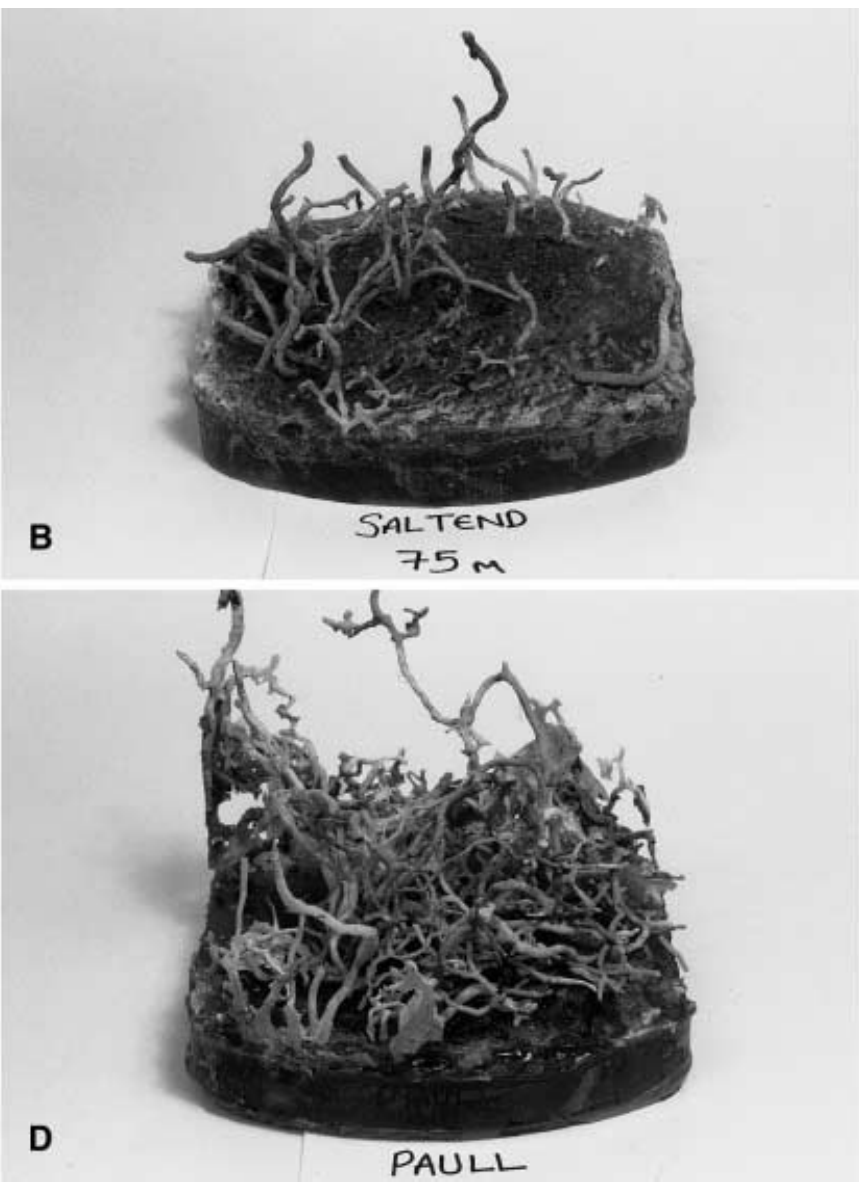

the community was dominated by regenerators, which may explain the smooth profile. The resin burrow casts in Fig. 6 clearly show why beads were transported to much greater depths as the level of pollution declined. Further evidence for increasing bioturbation potential with declining levels of pollution is provided by the total sediment modification scores for each community. This scoring system could be greatly improved if abundance, biomass and animal size were considered. For example, at Paull, Nephtys, Eteone and Pholoe all contribute significantly to increasing the score for this site yet they occur at such low densities that their effects on the sediment may be minor. Davey and Partridge (1998) suggest that, in terms of sediment mixing, the effects of Nephtys are small and mediated only slowly over time. In addition, the greater occurrence of the larger Nereis and the greater biomass at the $200 \mathrm{~m}$ site than at the $75 \mathrm{~m}$ site suggests that bioturbation should be greater at the $200 \mathrm{~m}$ site. This was indeed the case, as indicated by the glass bead study. However, this technique would not detect the difference and here it is only due to the presence of $M a$ nayunkia aestuarina that the score was increased. Despite this, the Swift (1993) scoring system does show a distinct pattern of increasing bioturbation with distance from the pollution outfall. Changes in bioturbation potential in relation to pollution have also been observed by Winston and Anderson (1971) who studied the effects of an oil spill in New Hampshire and other environmen- 
tal effects such as season, temperature, position on the shore (Retraubun et al. 1996) and salinity (Winston and Anderson 1971) are also known to affect bioturbation.

The reduction in bioturbation found here can be attributed to the fact that whilst animal abundance increases, species diversity and community biomass are significantly lower at the most contaminated sites $(25 \mathrm{~m}$ and $75 \mathrm{~m}$ ). This is typical of faunal patterns along organic gradients, as documented by Pearson and Rosenberg (1978). In addition, these authors also demonstrated a progressive simplification of trophic variety in response to increasing organic enrichment and found a general decline in carnivorous and selective surface deposit feeding species to be coupled with an increase in non-selective sub-surface deposit feeders. They also suggested that communities at the more polluted end of the scale were entirely composed of detritus feeders. These findings are broadly consistent with the results of this study, where there is a distinct increase in the diversity of feeding guilds with reducing levels of pollution. Given that bioturbation and feeding are so closely related (Rhoads 1974; Rhoads and Boyer 1982), it is not surprising that pollution also results in a reduction in the diversity of bioturbation guilds, a feature reflected in the use of the Infaunal Trophic Index to denote pollution status (Elliott 1993).

According to Jumars and Nowell (1984), several attempts have been made to classify benthic organisms into functional groups. This has been largely unsuccessful since organism behaviour may change depending on the environmental conditions and an organism may also have various simultaneous effects on its environment through performing a single activity. For example, deposit feeders such as $N$. diversicolor (Nielsen et al. 1995) and M. balthica (McLusky and Elliott 1981) are known to be capable of suspension feeding and may change between the two over a tidal cycle. Pygospio elegans and Streblospio shrubsoli are also able to alternate between deposit and suspension feeding (Fauchald and Jumars 1979) and there is increasing evidence for this plasticity in feeding (Pearson and Rosenberg 1978; Snelgrove and Butman 1994). Given that deposit feeding is usually associated with a high level of bioturbation and is classed as a destabilising activity, and suspension feeding generally encourages deposition, a change in feeding behaviour will also mean a change in sediment modification potential. However, despite their problems, broad classifications are considered generally useful in describing some of the dominant processes in a community (Pearson and Rosenberg 1978; Dauwe et al. 1998).

The results of the bioturbation studies and faunal community analysis may be linked to the sediment properties which show water content and oxygen penetration to increase with distance from the source of pollution. Burrow depth, volume and density also increased with a reduction in pollution. With this, a reduction in sediment shear strength was found although this result should be treated with caution since the transect ran from the upper shore towards the mid-shore and emersion period will in- fluence sediment drying. Nevertheless, an increase in burrow volume will result in an increase in sediment water content and so it is likely that changes in sediment shear strength are due to a combination of position on the shore and faunal activity. Pearson and Rosenberg (1978) also stated that a reduction in burrow size, depth and complexity, resulting from a change in trophic structure, will result in increased stability.

\section{Implications for sediment stability}

Jumars and Nowell (1984) described four broad modes of organism effect on the sediment which may either enhance erosion or encourage deposition. Firstly, biogenic structures alter the properties of the flow by altering the surface roughness of the bed (Nowell et al. 1981). The fluid momentum incident on the surrounding bed may either be increased or decreased as a result of the presence of various structures. Eckman et al. (1981) found that coverage by tubes of the polychaete Owenia fusiformis, of a flume sample by up to $4 \%$ enhanced erosion. They also stated though that in addition to density, this effect was dependent on tube roughness, geometry, the height:width ratio and the presence of microbial films. At higher densities, erosion was reduced and deposition enhanced, an observation which has also been made in seagrass beds (Scoffin 1970, in Jumars and Nowell 1984). Nowell et al. (1981) concluded that any activity producing structures large enough to approach the thickness of the viscous sub-layer would alter the fluid stresses on the bed both up- and downstream of the structure, potentially affecting erosion. At Skeffling (east of Paull and Saltend), P. elegans and S. shrubsoli were both classed as stabilising organisms by Widdows et al. (1998a,b). However, at Paull, dense tube mats do not occur and so it is unlikely that any stabilisation would be caused due to the presence of these worms. In addition, the tubes of these species are generally small and so it is questionable whether isolated tubes would have the effect of significantly enhancing erosion.

Particle exposure to the flow is also altered by, for example, the production of tracks or faecal mounds. It has been reported (Fenton and Abbot 1977, in Nowell et al. 1981) that for coarse material $(>2.5 \mathrm{~mm}$ diameter), a protrusion of half the particle diameter above the bed would reduce the critical erosion velocity by a factor of 1.7. In general, the critical erosion velocity is higher for consolidated sediments and it would therefore be expected that unconsolidated faecal pellets would be more easily resuspended than ambient sediments. This has indeed been observed by Sternberg (1972, in Nowell et al. 1981) and the faecal pellets of oligochaetes have been found to have settling velocities twice that of other particles but, in that study, the critical erosion velocities were much lower. This suggests that the presence of large numbers of oligochaetes, as found in the present study (e.g. $25 \mathrm{~m}$ and $75 \mathrm{~m}$ at Saltend) may potentially increase sediment transport. C. volutator also deposits faeces at 
the surface and may therefore influence sediment transport at Paull and the $200 \mathrm{~m}$ site. The transportation of faeces is, however, complicated by the presence of stabilising bacteria and shape. For example, cylindrical pellets tend to be rapidly destroyed, whereas discoidal pellets, such as those from $M$. balthica are readily transported intact (Schafer 1972, in Nowell et al. 1981).

In addition, animal activity alters particle momentum by, for example, the ejection of watery plumes of faecal and pseudofaecal material into the water column and increasing the erosion potential (e.g. tellinid bivalves; Bender and Davis 1984; Davis 1993). Species such as these, which plough through the sediment, also have the effect of reducing consolidation and work concerning the effect of these organisms on the sediment properties suggests that the destabilising effects far outweigh any stabilising effects of these organisms (Davis 1993). It is suggested that the presence of Macoma at Paull will indicate increased erosion potential compared to Saltend. However, the densities are still very low at Paull $\left(9 \mathrm{~m}^{-2}\right)$ whereas at Skeffling in the Humber they reach densities of many thousands $\mathrm{m}^{-2}$ (Widdows et al. 1998a,b).

Mucopolysaccharide production by benthic organisms, especially microphytobenthos, can potentially enhance sediment stability due to changes in the adhesive properties of the individual particles (Underwood and Smith 1998). Although adhesive forces resulting from animal/microbial activity are of great importance in governing sediment erodibility, the relationship between the two is complex and poorly understood. For example, deposit feeding organisms must break the bonds between particles during feeding which is potentially destabilising but during feeding, movement and excretion, these bonds are reformed as a result of mucous secretion. The suspension feeding bivalve Transenella tantilla which produces crawling traces, thus altering particle exposure to the flow and enhancing erosion, also produces mucous which may help to stabilise these tracks (Jumars and Nowell 1984). Furthermore, animal activity enhances the growth of microbial populations which also secrete stabilising mucous (Underwood and Smith 1998), although this can be counteracted by grazing (Grant and Daborn 1994) by species such as $N$. diversicolor and $C$. volutator which become increasingly abundant with reducing levels of pollution. In addition to increasing particle adhesion, mucilages also increase particle deposition by reducing the probability of resuspension once a particle has come into contact with and stuck to the bed.

Several studies (e.g. Bender and Davis 1984; Meadows and Tait 1989; Davis 1993; Grant and Daborn 1994) have attempted to classify benthic species in terms of their sediment modification behaviour but the effects of an organism are variable and numerous and most results have been contradictory. This is particularly the case for species found to be important in the present study, such as $N$. diversicolor and $C$. volutator (Meadows and Tait 1989; Underwood and Paterson 1993). However, as current speeds increase, the importance of bioturbation and animal activity probably reduces as biogenic structures disappear and transport becomes predominantly the result of high current speeds (Jumars and Nowell 1984), although more recent laboratory and field studies by Widdows et al. (1998a,b) have shown an interaction between Macoma bioturbation and current velocity. Density dependent bioturbation, through loosening of surface sediments, was found to increase resuspension over a range of currents and not simply at low currents.

\section{Conclusion}

In general, pollution does reduce bioturbation potential, demonstrated by the transport of glass beads, the use of sediment modification potential scores and by resin casting of burrows. Bioturbation is reduced as a result of decreasing species diversity and community biomass, as well as diversity of feeding and bioturbation groups. This suggests that the potential for sediment transport may, as a result of shallower burrowing and reduced grazing pressure, be decreased by pollution. However, the relationship between animal activity and sediment transport is complex and as indicated here, subject to many influences.

Acknowledgement Thanks go to BP Chemicals (Saltend) Ltd for their financial assistance.

\section{References}

Barnes RD (1987) Invertebrate zoology, 5th edn. Saunders, College, $\mathrm{Pa}$.

Bender K, Davis WR (1984) The effect of Yoldia limatula on bioturbation. Ophelia 23:91-100

Buchanan JB (1984) Sediment analysis. In: Holme NA, McIntyre AD (eds) Methods for the study of marine benthos, 2nd edn. Blackwell, Oxford, pp 41-65

Cambridge Coastal Research Unit (1996) Saltend invertebrate community monitoring and heavy metal accretion analysis. Report to BP Chemicals (SR086347/JA/). University of Cambridge

Dauwe B, Herman PMJ, Heip CHR (1998) Community structure and bioturbation potential of macrofauna at four North Sea stations with contrasting food supply. Mar Ecol Prog Ser 173:67-83

Davey JT, Partridge VA (1998) The macrofaunal communities of Skeffling muds (Humber estuary), with special reference to bioturbation. In: Black KS, Paterson DM, Cramp A (eds) Sedimentary processes in the intertidal zone. (Special Publication 139) Geological Society, London, pp 85-97

Davis WR (1993) The role of bioturbation in sediment resuspension and its interaction with physical shearing. J Exp Mar Biol Ecol 171:187-200

Eckman JE, Nowell ARM, Jumars PA (1981) Sediment destabilisation by animal tubes. J Mar Res 39:361-374

Elderfield H, Hepworth A (1975) Diagenesis: metals and pollution in estuaries. Mar Poll Bull 6:85-87

Elliott M (1993) Recent developments in macrobenthic community analysis. In: Papathanassiou E, Chosoll E (eds). Proceedings of the 4th National Symposium on Oceanography and Fisheries. Rhodes 26-29 April, pp 144-155

Elliott M, Dewailly F (1995) The structure and components of European estuarine fish assemblages. Neth J Sea Res 29:397-417

Fauchald K, Jumars PA (1979) The diet of worms: a study of polychaete feeding guilds. Oceanogr Mar Biol Annu Rev 17:193-284 
Gerino M, Stora G, Gontier G, Weber O (1993) Quantitative approach of bioturbation on continental margins. Ann Inst Oceanogr 63:177-181

Grant J, Daborn G (1994) The effects of bioturbation on sediment transport on an intertidal mudflat. Neth J Sea Res 32:63-72

Gray JS (1981) The ecology of marine sediments: an introduction to the structure and function of benthic communities. Cambridge University Press, Cambridge

Hickson JA (1994) The role of the bivalve Macoma balthica (L) from the Humber estuary in the bioturbation of sediments. MSc thesis, University of Hull

Institute of Estuarine and Coastal Studies (1996) Humber estuary: benthic invertebrate and saltmarsh survey. (Report ZO73-96-F) University of Hull

Jones NS (1950) Marine bottom communities. Biol Rev 25:283-313

Jones SE, Jago CF (1993) In situ assessment of modification of sediment properties by burrowing invertebrates. Mar Biol 115:133-142

Jumars PA, Nowell ARM (1984) Effects of benthos on sediment transport: difficulties with functional grouping. Cont Shelf Res $3: 115-130$

Krezoski JR, Oladipo M, Adjarova L, Shick C, Tisue T (1995) Caesium labelled phlogopite as a tracer for in-situ studies of sediment burial, reworking and resuspension rates. Int J Environ Anal Chem 59:213-223

Libes SM (1992) An introduction to marine biogeochemistry. Wiley, New York

Lorenzen CJ (1967) Determination of chlorophyll and phaeopigments: spectrophotometric equations. Limnol Oceanogr 12:343-346

Ludwig JA, Reynolds JF (1988) Statistical ecology: a primer on methods and computing. Wiley, New York

Mahut ML, Graf G (1987) A luminophore tracer technique for bioturbation studies. Oceanol Acta 10:323-328

Marshall S, Elliott M (1998) Environmental influences on the fish assemblage of the Humber estuary, UK. Estuarine Coast Shelf Sci 46:174-184

McLusky DS, Elliott M (1981) The feeding and survival strategies of estuarine molluscs. In: Jones NV, Wolff WJ (eds) Feeding and survival strategies of estuarine organisms. Mar Sci 15:109-121

Meadows A (1991) Burrows and burrowing animals: an overview. In: Meadows PS, Meadows A (eds) The environmental impact of burrowing animals and animal burrows. (Symp Zool Soc Lond 63) Clarendon, Oxford, pp 1-13

Meadows PS, Tait J (1989) Modification of sediment permeability and shear strength by two burrowing invertebrates. Mar Biol 101:75-82

Nickell LA, Atkinson RJA (1995) Functional morphology of burrows and trophic modes of three thalassinidean shrimp species, and a new approach to the classification of thalassinidean burrow morphology. Mar Ecol Prog Ser 128:181-197

Nielsen AM, Eriksen NT, Iversen JJL, Riisgard HU (1995) Feeding, growth and respiration in the polychaetes Nereis diversicolor (facultative filter feeder) and Nereis virens (omnivorous) - a comparative study. Mar Ecol Prog Ser 125:149-158

Nowell ARM, Jumars PA, Eckman JE (1981) Effects of biological activity on the entrainment of marine sediments. Mar Geol 42:133-153

Olmez I, Pink FX, Wheatcroft RA (1994) New particle labelling technique for use in biological and physical sediment transport studies. Environ Sci Technol 28:1487-1490

Pearson TH, Rosenberg R (1978) Macrobenthic succession in relation to organic enrichment and pollution of the marine environment. Oceanogr Mar Biol Annu Rev 16:229-311

Petersen CGJ (1913) Valuation of the sea. II. The animal communities of the sea bottom and their importance for marine zoogeography. Rep Dan Biol Stat Board Agric 21:1-44
Retraubun ASW, Dawson M, Evans SM (1996) Spatial and temporal factors affecting sediment turnover by the lugworm Arenicola marina (L.). J Exp Mar Biol Ecol 201:23-35

Rhoads DC (1967) Biogenic reworking of intertidal and subtidal sediments in Barnstable Harbour and Buzzards Bay, Massachusetts. J Geol 75:461-476

Rhoads DC (1974) Organism-sediment relations on the muddy sea floor. Oceanogr Mar Biol Annu Rev 12:263-300

Rhoads DC, Boyer LF (1982) The effects of marine benthos on physical properties of sediments: a successional approach. In: McCall PL, Tevesz MJS (eds) Animal-sediment relations: the biogenic alteration of sediments. (Topics in geobiology, vol 2) Plenum, London, pp 1-52

Rhoads DC, Young DK (1970) The influence of deposit feeding organisms on sediment stability and community trophic structure. J Mar Res 28:150-178

Sanders HL (1958) Benthic studies in Buzzards Bay. I. Animalsediment relationships. Limnol Oceanogr 3:245-258

Smethie WM, Nittrouer CA, Self RFL (1981) The use of Radon222 as a tracer of sediment irrigation and mixing on the Washington continental shelf. Mar Geol 42:173-200

Snelgrove PVR, Butman CA (1994) Animal -sediment relationships revisited: cause versus effect. Oceanogr Mar Biol Annu Rev 32:111-177

Swift DJ (1993) The macrobenthic infauna off Sellafield (north eastern Irish Sea) with special reference to bioturbation. J Mar Biol Assoc UK 73:143-162

Underwood GJC, Paterson DM (1993) Seasonal changes in diatom biomass, sediment stability and biogenic stabilisation in the Severn estuary. J Mar Biol Assoc UK 73:871-887

Underwood GJC, Smith DJ (1998) In situ measurements of exopolymer production by intertidal epipelic diatom-dominated biofilms in the Humber estuary. In: Black KS, Paterson DM, Cramp A (eds) Sedimentary processes in the intertidal zone. (Special Publication 139) Geological Society, London, pp 125-134

Wheatcroft RA (1992) Experimental tests for particle size dependant bioturbation in the deep ocean. Limnol Oceanogr 37:90-104

Wheatcroft RA, Martin WR (1996) Spatial variation in short term $\left({ }^{234} \mathrm{Th}\right)$ sediment bioturbation intensity along an organic carbon gradient. J Mar Res 54:763-792

Wheatcroft RA, Olmez I, Pink FX (1994) Particle bioturbation in Massachusetts Bay: preliminary results using a new deliberate tracer technique. J Mar Res 52:1129-1150

Widdows J, Brinsley M, Elliott M (1998a) Use of in-situ flume to quantify particle flux (biodeposition rates and sediment erosion) for an intertidal mudflat in relation to changes in current velocity and benthic macrofauna. In: Black KS, Paterson DM, Cramp A (eds) Sedimentary processes in the intertidal zone. (Special Publication 139) Geological Society, London, pp 85-97

Widdows J, Brinsley MD, Salkeld PN, Elliott M (1998b) Use of annular flumes to determine the influence of current velocity and bivalves on material flux at the sediment-water interface. Estuaries 21:552-559

Wilde PAWJ de (1991) Interactions in burrowing communities and their effects on the structure of marine benthic ecosystems. In: Meadows PS, Meadows A (eds) The environmental impact of burrowing animals and animal burrows. (Symp Zool Soc Lond 63) Clarendon, Oxford, pp 107-117

Winston JE, Anderson FE (1971) Bioturbation of sediments in a northern temperate estuary. Mar Geol 10:39-49

Wolff WJ (1984) Flora and macroflora of intertidal sediments. In: Baker JM, Wolff WJ (eds) Biological surveys of estuaries and coasts. Cambridge University Press, Cambridge, pp 81-104

Zar JH (1996) Biostatistical analysis, 3rd edn. Prentice Hall, Englewood Cliffs 